„Analiza i Egzystencja” 39 (2017)

ISSN 1734-9923

DOI: 10.18276/aie.2017.39-02

\title{
RATIONAL VS. MYSTICAL READINGS OF ARISTOTLE'S NOUS POIETIKOS. INTRODUCTION TO THE SUBJECT AND OVERVIEW OF CENTRAL POSITIONS
}

Keywords: nous poietikos, mystical and rational readings, Aristotle, psychology, God/Deity, immortality, intellectual soul, unio mystica

Słowa kluczowe: nous poietikos, interpretacje mistyczne i racjonalistyczne, Arystoteles, psychologia, Bóg/Bóstwo, nieśmiertelność, dusza rozumna, unio mystica

\section{Introduction}

Nous poietikos, introduced by Aristotle in De Anima 3.5, has always been one of the central issues of philosophical reflection. It is vital not only to understand Aristotle, but also his pupils (both immediate and the ones who came later), as well as his predecessors (see: the manifold analogies to

* Sonia Kamińska, Ph.D. - Jagiellonian University, Institute of Philosophy. Funding: My research (2015/19/D/HS1/00969) was financed from the assets awarded by The National Science Centre, Poland upon the decision no. DEC-2015/19/D/HS1/00969. Current project: Mystical and rational readings of Aristotle's psychology, and especially of nous poietikos, National Science Centre, Poland, 2016-2019.

Address for correspondence: Jagiellonian University, Institute of Philosophy, Grodzka 52, 31-044 Kraków. E-mail: kaminska.sonia@gmail.com. 
Anaxagoras and his ruling nous, for instance). The urge to grasp the essence of intellectual soul has always driven our civilisation towards new questions and theories. It was vital even in the age of retreat from Aristotelian thought. Despite all this unflagging interest, the question of its true nature is still far from being solved. I will not unravel it here either, as this would be a breakneck project. What I will do however, is to systematize the existing interpretations.

\section{What is nous poietikos?}

Let me start by quoting the whole chapter 5 from the third book (430a) of Aristotle's De Anima, both in Greek and in English:

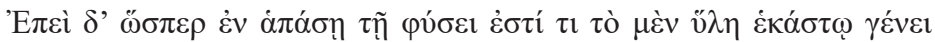

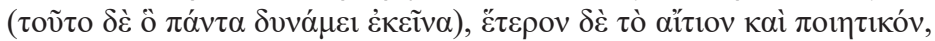

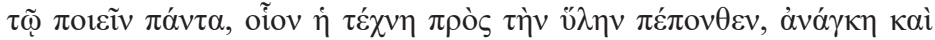

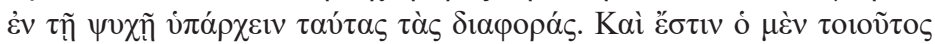

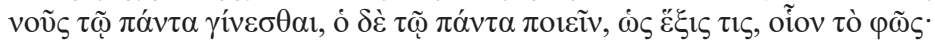

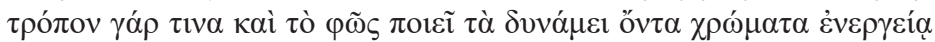

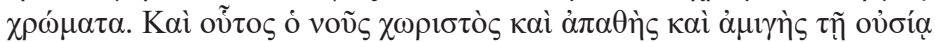

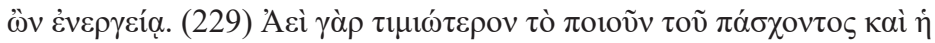

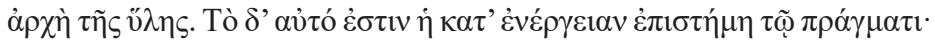

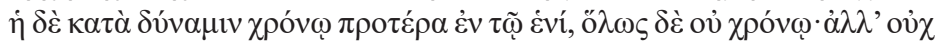

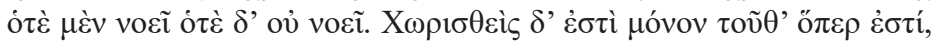

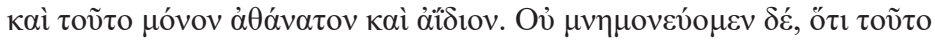

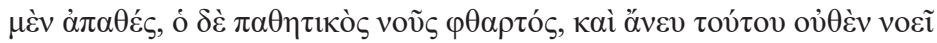
(Bekker, Berolini [Berlin] 1837).

Since in every class of things, as in nature as a whole, we find two factors involved, (1) a matter which is potentially all the particulars included in the class, (2) a cause which is productive in the sense that it makes them all (the latter standing to the former, as e.g. an art to its material), these distinct elements must likewise be found within the soul. And in fact mind as we have described it is what it is in virtue of becoming all things, while there is another which is what it is by virtue of making all things: this is a sort of positive state like light; for in a sense light makes potential colours into actual colours. Mind in this sense of it is separable, impassible, unmixed, since it is in its essential nature activity (for always the active is superior to the passive factor, the originating force to the matter which it forms). 
Actual knowledge is identical with its object: in the individual, potential knowledge is in time prior to actual knowledge, but in the universe as a whole it is not prior even in time. Mind is not at one time knowing and at another not. When mind is set free from its present conditions it appears as just what it is and nothing more: this alone is immortal and eternal (we do not, however, remember its former activity because, while mind in this sense is impassible, mind as passive is destructible), and without it nothing thinks.

(trans. J.A. Smith) ${ }^{1}$

This short passage (430a) is a tricky one and thus many interpreters and commentators ${ }^{2}$ have cut their teeth on it. Commentaries and translations are inescapably interpretations and thus the responsibility that rests with the translators is substantial. Let me illustrate this by comparing two translations of this passage: Polish and English. I wish to concentrate on the

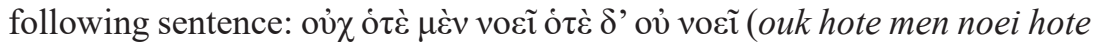
d'ou noei). Smith's translation reads: "Mind is not at one time knowing and at another not". Paweł Siwek's translation, on the other hand, reads: "Mind is at one time knowing and at another not". From the philological point of view, Smith is right and Siwek is wrong. But if we take a closer look at this puzzle, we will see what lines of interpretation underpin their linguistic decisions. According to the English version it is impossible for the mind to be at rest, which may imply its divine nature. Siwek, on the other hand, believes that mind belongs to us and it is up to us, if and when we use it or not. Probably, English translation by "mind" reads "active intellect", and the Polish one - "mind as a whole" (passive and active aspects together). Mind as a whole is not always at work, it needs to be activated by the superior component in order to actively think (Modrak, 1991).

This was just a short digression in order to show how unclear this passage is and on what shaky ground we stand here.

Despite all this, the passage is by far one of the most important texts of the wide Aristotelian tradition by which I understand history of philosophy, psychology, philosophy of mind, philosophy of religion, ontology, metaphysics, to mention just a few areas of scholarly interest. Aristotle introduces here

\footnotetext{
${ }^{1}$ Aristotle (2017).

2 The most important commentaries of De Anima are the ones by Alexander of Aphrodisias and Themistius.
} 
a nameless second intellect which we now know under the name of nous poietikos (stemming from the Greek "poieo": to do, to make, to produce, to act). Aristotle speaks of two faculties in the intellectual soul and we cannot determine whether he thinks of an individual soul or a natural kind (the interpretations vary significantly in this respect). Moreover, we cannot be sure whether these are substances equipped with powers or powers themselves that pile up to a substance (or not). One of these faculties is characterised as passive/receptive and the other one - as active/actual and in this sense divine. The latter is to the former (introduced in De Anima 3.4) like art to its material or light to potential colours (see the quotation above). The first one to some extent depends on the body (senses and memory) and thus is perishable, whereas the second one does not die alongside the decomposing matter, because it is separate (choristos) from the body. Interestingly, neither the passive nor the active mind have a respective organ in the body. Some commentators divide the intellectual soul into three faculties and thus they postulate a receptive intellect located "between" the passive and the active one.

\section{Carry on regardless}

I believe it is now clear, that De Anima 3.5 is a highly controversial passage; succinct and enigmatic at the same time. It is ambiguous, stuffed with unclear points and metaphors. Instead of turning away from it as a fabric of contradictions, philosophers got really obsessed with it and the quest for nous poietikos's real function continues in the present day. And the question to be asked here seems a bit paradoxical: what is the activity of the active intellect? We can sensibly assume that it does something and that thanks to this action it is better, more sublime than the passive one. Unfortunately, Aristotle describes it in a metaphorical way and moreover he says that we do not remember its performance or in other renditions, that we do not understand it. And thus, I believe, we are left with the mystical descriptions of it as our last resort, because the rational language simply fails. If we grasped its right function, we would be able to provide a reasonable account of its ontological status and finally decide whether it is a tool in the realm of human psychology and the individual cognitive apparatus, or an impersonal sphere in which the lower faculties of individual persons participate, or last but not 
least - God or Deity. An alternative way is to establish the "owner" - man or God - first. We can also resort to other works by Aristotle. For instance, in De generatione animalium 2.3 Aristotle speaks of the divine seed (see: theion sperma, pneuma sumphuton) which I believe to be an equivalent of nous poietikos. Below I will also mention Metaphysics 12.9 and Nicomachean Ethics, book 10.

Some, like Alexander of Aphrodisias, and from the contemporary philosophers - Victor Caston, want their theories to be very efficient and thus identify nous poietikos with the Deity in order to obtain a modest ontology. Caston (1999) admits, that his position is inspired by Alexander of Aphrodisias. What they have in common is the identification of nous poietikos with the Deity, but only in case of Alexander the Deity is the cause of everything and the ground of all being. And Caston maintains that there is no action that we could ascribe to the Deity, and no wonder no one has ever fully indicated it, since the Deity is idle. Moreover, the quest for its function looks like the quest for the Holy Grail and is in itself ludicrous. Caston calls it "a wild goose chase". Others, like Aryeh Kosman (1992) claim that nous poietikos does have a specific function. Kosman even suggests calling it "a maker mind". Also, Franz Brentano (1911b/1978), whom I consider to be one of the most important Aristotelian scholars (despite his interpretation being far from flawless), believes that there is a specific function and he calls it "moving our thoughts from potentiality to actuality". There are also intermediate positions, according to which nous poietikos is just our knowledge that allows us to think the things that we know (Macfarlane, Polansky, 2009) rather loosely inspired by Arabic Aristotelianism (Averroes).

\section{Interpretational key}

My "key" to ordering these interpretations will be a demarcation between "mystical" and "rational" ones. What inspires me here is Rolf George's (1977) opinion expressed in the introduction to his translation of Franz Brentano's Habilitationsschrift (1867). George claimed there that Brentano was against all the mystical elements and traces in the interpretation of Corpus Aristotelicum. Interestingly, Brentano himself does not explicitly declare a war against mysticism and does not use this highly useful (but also 
controversial) label. ${ }^{3}$ George's remark was pointed at Brentano's life-long discussion with Eduard Zeller (e.g. in Brentano 1911a, 1980). Interestingly, if one scrutinizes all the concepts Brentano denounces in his Habilitationsschrift on Aristotle's psychology from 1867, one will see clearly that they have a lot in common and if we agree to call Zeller a mystic, we might as well use this label for the rest of the criticised thinkers. The traits in common are: separation of nous poietikos from the individual cognitive apparatus, identification of nous poietikos with God/Deity or at least a divine sphere with which humans get in touch via sort of a union, impossibility of individual immortality of intellectual soul. Like Thomas Aquinas, Brentano believed, that nous poietikos is an individual device, given to us by God, a device to be used in order to achieve what Aristotle called a perfect life already on earth and as a result - obtain immortality, again: in the sublunary world (this kind of immortality very much resembles the so called unio mystica). George called Brentano a "rationalist" in contrast to the partisans of the abovementioned cluster of mystical features. The latter "group" - I must say - was treated rather unjustly by Brentano and I wish to do more justice to these thinkers by elaborating on their views.

Along these lines, I decided to introduce a division into mystical and rational readings (although I am aware that in this case these terms do not render the dictionary meaning properly). I will use this criterion not only to analyse the theories enumerated by Brentano $(1867,1977)$ in the brief, introductory part of the book (Theophrastus, Eudemus, Alexander of Aphrodisias, Thomas Aquinas, Avicenna, Averroes, Christian Brandis, Eduard Zeller, Friedrich Trendelenburg, et al.), but also to some of the contemporary readings of nous poietikos (Victor Caston, Aryeh Kosman, Patrick Macfarlane \& Ronald Polansky, et al.).

3 He openly criticized mysticism some time later, though; in his The Four Phases of Philosophy and its Current State (1895). However, the mysticism he had in mind in The Four Phases... is not identical with the one I propose and formulate in this paper. In The Four Phases... Brentano claimed that history of philosophy goes through phases of development and decline, mysticism being the most degenerated stage of the latter. 


\section{A closer look}

Let me repeat: the so called "mystics" claim that nous poietikos is an uncreated, eternal Deity or a divine sphere emanating ${ }^{4}$ from the Deity, totally divorced from human nature but acting upon us. The "rationalists" on the other hand claim, that it is a faculty which belongs to human psychology and that it serves to attain the Deity on the path of theoretical contemplation. In the Christian version of "rationalism" God is not an impersonal Deity, but both first principle and a person who is responsible for creating nous poietikos for us and implementing it distributively.

Below, I will present ancient and medieval thinkers in the chronological order and thus I wish to illustrate the development phases of Aristotelianism or - more precisely - Aristotelian psychology. I am fully aware that this is an arbitrary choice of names shaped by my past and current interests and projects, and not an objective, exhausting list of Aristotelian scholars and commentators. For instance, I am not including the renaissance antiThomistic Averroists, as I cover this subject in another study which is yet in progress. I hope, nevertheless, that my choice will be sufficient to present the issue in question adequately.

\section{Theophrastus and Eudemus - an Initial Discord}

Let me begin with Theophrastus (371-287 B.C.) who was the successor to Aristotle in Peripatos and who believed that nous poietikos was immaterial, that it belonged to the nature of man, i.e. to his intellectual soul. On the other hand, Eudemus (370-300 B.C.) who was Aristotle's student and an editor of his writings identified nous poietikos with Deity (see for instance Eudemian Ethics). So, we can see that there was no unanimity even between the immediate followers of Aristotle, which may seem rather puzzling as they were both very close to their master. Theophrastus can be called a rationalist, whereas Eudemus undoubtedly earned the name of a mystic. What could have caused this discrepancy? I will come back to that question later on.

\footnotetext{
${ }^{4}$ The emanation can be associated with Neoplatonism.
} 


\section{Alexander of Aphrodisias}

The next important thinker is Alexander of Aphrodisias (head of the school in Athens, 198-211) who followed in Eudemus's footsteps. I have decided to concentrate on Alexander and devote some extra attention to him, as I find his position crucial for understanding the mystical reading, and I am aware that it is less popular than the rationalist one. According to Alexander nous poietikos is a purely spiritual substance, separate from the nature of man and acting upon him. In fact, it is the divine intelligence itself (Deity), the ground of all things. This view has this consequence that human soul or what is left after "removing" the active intellect is fully dependent on the body. And everything that is entirely dependent on the body, must be mortal. Because the active intellect is one and the same for all people, it can be called "a common good". As a result, individual immortality is impossible, but a collective one is available - or so it seems. I will develop this issue below.

Alexander of Aphrodisias was one of the greatest, if not the greatest commentator of Aristotle and is much admired by some of the contemporary Aristotelians (e.g. V. Caston, I. Kupreeva, as well as the author of this paper). His interpretation was very thorough and some believe that he went even further in defining the notorious nous poietikos than Aristotle would ever dare. Since the interpretation of active intellect is the climax of his interpretation, I shall begin by sketching the background. For years he was considered to be a materialist and a nominalist. But the $\mathrm{XX}^{\text {th }}$ century brought a completely new reading of Alexander according to which he was an anti-naturalist, a mystic and a pre-neo-platonic thinker. Giovanni Reale (1990) calls it "a twist" and claims it is an another, totally unexpected face of Alexander. Below I will show that these two faces are perfectly complementary and that there's no twist, rather a jigsaw falling into place. I believe Alexander's view on human soul is a reflection of his view on universals which, some claim, was more radical than Aristotle's. His nominalism (accepting the existence of individuals only) led him to the position that a form cannot exist beyond matter - and this is why human soul is perishable and cannot live without the body. This is a very audacious claim and no wonder it causes doubts. Even more so, because we are used to the interpretation according to which our intellectual soul lives happily ever after (even if we are not religious). Didn't Aristotle say that in De Anima 3.5? Didn't many commentators afterwards confirm that in various ways over the years? Thomas Aquinas being the most 
famous partisan of this view. But if we look closer at De Anima 3.5 we'll see that it is not impossible that "the other intellect" that was claimed ours and immortal, is in fact not ours, but divine. And our soul, our private one is like our bodies - perishable. So, what does it look like according to Alexander? We are all used to think that we have two intellects: passive (able to become all things) and active (able to do everything). And why is that? Because Aristotle said there are two... "Since in every class of things, as in nature as a whole, we find two factors involved, 1) a matter which is potentially all the particulars included in the class, 2) a cause which is productive in the sense that it makes them all (the latter standing to the former, as e.g. an art to its material)", these distinct elements must likewise be found within the soul (trans. J.A. Smith). Alexander takes the second one away from us and identifies it with God / Absolute / the Prime Mover. What is left - he divides in two parts: intellectus materialis and intellectus in habitu. The material intellect is a pure possibility, a possibility to know all things (both sensible and intelligible). The other one has already actualized its potentiality and acquired its proper perfection of thinking, that is habitus (hexis). Intellectus in habitu is already capable of abstracting the form from the matter. For instance, Franz Brentano, would say this is the role of the active intellect which belongs to us as a tool. According to Alexander, nous poietikos - the active intellect aka. Deity is productive. It means it is the cause that makes it possible for the material intellect to abstract the form from the matter and thus become the intellectus in habitu.

I think it is very hard (almost impossible) to formulate a plausible account of immortality, but it is even harder to resign from it and accept that things must end. It is a classic lose - lose situation. Even Reale (1990) seems to be led astray here, when he says that maybe by positing a Deity identical with nous poietikos, Alexander invented a new type of immortality - an impersonal one. I shall question this contend. Impersonal immortality is when our intellectual souls lose their identity yielded by the bodies and "join" an impersonal sphere or a reservoir of knowledge, if I may say so (for more see the description of Macfarlane \& Polansky's position below). In this case this is just straight mortality for us and immortality for the Deity. Only, in the latter case it sounds almost redundant to call a Deity immortal since it is immortal by its very nature. On the other hand, the discourse of human immortality makes sense, since it is a way of comparing humans to gods and thus elevating us. 
Is "the thing" Alexander takes away from us so important after all? And does he really take it away? I mean, was it there in the first place? Did Aristotle give it to us? Reale (1990) says that by removing the active intellect from human soul Alexander steers away from his Master. But, does he really? Actually, it is now becoming more common to think that Aristotle, in 3.5, didn't mean "our" soul, but the soul, as a kind, which means he didn't provide us with a godlike immortal soul (see Caston, 1999). When we think "our soul", we fall prey to a trick we play on ourselves as we are unbearably anthropocentric. In addition, Alexander seems to be in accordance with Nicomachean Ethics, book 10, where Aristotle describes the perfect, most sublime activity which is only available for philosophers - theoria. And eudaimonia, the perfect happiness achieved on the path of theoria is - I believe - resembled in Alexander's description of the mystical union between singular mind and the divine one. In both cases there's no individual immortality, but there is a quasi-immortality attainable in the sublunary world. It is worth stressing that such a position enables identity with the Deity (see: Actual knowledge is identical with its object..., De An. $3.5)$, even if for a short while, whereas the rationalist view provides only similarity in the relationship Deity - humans.

\section{Arabic Aristotelianism}

Then there came the Arabic Aristotelianism in the persons of Avicenna and Averroes, to mention the most famous ones. ${ }^{5}$ In this very paper, I will concentrate on Avicenna, as I find his position highly interesting and inspiring.

According to Avicenna (980-1037) the active intellect cannot be found in the human being as a subject. It is purely intellectual and separated from the nature of man. It imparts intelligible forms to the material intellect. I quote Franz Brentano (1977, p. 7): "The reason for this is that all intelligible forms pre-exist immaterially in the pure intellects (Geister), the intelligences, the highest of which moves the uppermost sphere, and the others the remaining heavenly spheres. From the highest intelligence,

${ }^{5}$ Unfortunately, including more Arabic philosophers here, would surpass the limits of this short, introductory paper. And it would be worthwhile to consider at least Al-Farabi and Al-Ghazali and I hope to do it in the near future. 
they flow into the second, from the second into the third, and so forth to the last, which is the so-called active intelligence (intelligentia agens)". Thus, as we can see, this is neither human power nor Deity, but something intermediary, that is a heavenly sphere. Interestingly, passive intellect, i.e. human soul can be immortal. Let me repeat, that it was mortal according to Alexander of Aphrodisias. The immortality of human soul according to Avicenna is unfortunately very cryptic. It is worth noticing that Avicenna authored an argument for the existence, independence and immortality of human soul called "the flying man" that is in many respects similar to the earlier cogito by St. Augustine and the later cogito by Descartes, ${ }^{6}$ Imagine - Avicenna says in Kitab Al-Shifa, The Book of Healing - a man, who has just been created. He is fully developed, but he does not use his senses at all. He is drifting in the air, his eyes closed, fingers splayed, his feet have never touched the ground, so he does not have any memories concerning sensory activities. Does such a human know about his own existence? He does, because he thinks - Avicenna answers. In addition, he knows, he is a soul and this soul is a unity independent from the body, hence its existence does not rely on physicality. The true "I" is the soul from which such consequences as its excellence and immortality follow. Analogously to Aristotle and Alexander of Aphrodisias, Avicenna believed that the intellectual soul and the body come into being at the same time. He dismissed the transmigration of the soul which was characteristic of Plato and Plotinus. On the other hand, he agreed with them that the soul can live on after the death of the body. This argument is based on his opinion about the relationship between body and soul which he claimed to be purely accidental and thus individual. So, when the body dies, it is the relationship that is over, not the soul. The soul survives and moreover - it retains its individuality. And this is where - I believe - the problems begin. Avicenna claims that the soul becomes individual and unique thanks to its relationship with the body, i.e. its earthy experience. How can this be if the relationship is only accidental? Moreover, the length of bodily life and the specific time spent on earth are supposed to matter in this case. There is another confusing question: can

${ }^{6}$ R. Sorabji (2006) claims that Porphyry could have been the common source for Augustine's and Avicenna's cogitos. In case of Avicenna and Descartes some believe that the latter one was strongly inspired by his predecessor. But R. Wisnovsky (2005) claims that this similarity is accidental and superficial. 
the soul, after the death of the body, get in touch with intelligentia agens? And if not, doesn't this diminish the quality of its existence if this was the sine qua non condition of its good life on earth? How come the quality of our immortality is a consequence of our behavior in the sublunary world if Avicenna claims that immortality follows from the nature of the soul and is not a mission to accomplish or a life goal? And - again - how can a body influence a soul to such an extent if their relationship is accidental and not essential? These questions need to be answered.

And according to Averroes (1126-1198), the active intellect is a purely intellectual substance which is by nature different from man as a sensitive being. Intellectus agens makes actually intelligible all the sensory pictures in man that are potentially intelligible and thus moves the material intellect. Like in Avicenna, there is one active mind for everybody. Unlike in Avicenna: both, material and active intellect are divorced from the nature of man, which is - in my opinion - a very brave if not audacious step. Knowledge is their union which can be understood as a rendition of Aristotle's words that actual knowledge is identical with its object (see: the quotation above). Humans as a species differ from animals on the basis of possessing a sensory (!) power, which is called intellect only by analogy (intellectus passibilis).

\section{Christian Aristotelianism and Creationism}

The Middle Ages bring yet another change and it is mostly due to the Christian Aristotelianism. Thomas Aquinas (1225-1274), whose position is still among the most popular ones (and this is why I am recapitulating it rather briefly here), believed that nous poietikos was an immaterial faculty of man, together with passive mind, building up an intellectual soul. It does not have a bodily organ. It was created and incarnated by God and is immortal. Moreover: we are immortal thanks to it. It is individual for every human being. I find it worthwhile that Aquinas is rather in agreement with Theophrastus, which may indicate that some of the ideas usually ascribed to medieval interpretations of Aristotle, stem from the Stagirite's immediate followers. But, there is a significant difference that must not be overlooked: Aquinas is a theist, i.e. he believes that God is a person. And that would be impossible in Antiquity. If an ancient god was a person, it would have been an Olympic god and when it comes to those, it must be stressed, that 
Aristotle used them metaphorically, while commenting on our good or bad luck in life (eutychia), and they had nothing to do with the first principle of all things. Deity was not a person, as this would deprive it of perfection, to say the least. Coming back to Aquinas: he also claimed, that God created us and equipped with this divine intellect during our fetal development (perfecta dispositio corporis). This is a possible rendition of Aristotle's concept of the divine seed (theion sperma) from De generatione animalium 2.3. Aquinas spitefully, but amusingly called Averroes "a dispoiler of Peripatetic philosophy" and the renaissance Averroists criticized him in return.

The Thomistic paradigm was no doubt a long-lasting one maintained also by the $\mathrm{XIX}^{\text {th }}$ century philosophers who belonged to a so called "Aristotelian revival”. Friedrich Adolph Trendelenburg (1802-1872), Franz Jakob Clemens (1815-1862) - both Brentano's teachers, Christian August Brandis (1790-1867), Franz Clemens Brentano (1838-1917), et al. claimed that nous poietikos was immaterial, perfectly fitted in the nature of man, individual for each human being, imparted from outside by God himself, the most sublime and divine part of human beings or a divine substance itself (but not identical with God). The XIX ${ }^{\text {th }}$ century Aristotelian revival was in fact a Christian-Aristotelian revival. There was also a distinguished Polish philosopher who should be mentioned in this context. He was a student of Brentano, who did not belong to this current, but no doubt shared most of their ideas. This thinker was Kazimierz Twardowski (see for instance Twardowski, 1895a, 1895b, 2009 where these ideas are explicitly expressed).

Interestingly, there were also some non-rationalist representatives of this current. For instance, the great philosophy historian Eduard Zeller believed that nous poietikos could be identified with the Deity (Zeller, 1886). And this is how he became Franz Brentano's "arch enemy" when it comes to Aristotelian studies. Brentano authored five books on Aristotle and he is a real record-holder in this respect. Much of what he wrote contains criticism directed at Zeller (for instance, Brentano 1911a, 1980 or his published letter to Zeller from 1883). Unfortunately, their discussion seems futile, as they agree (!) in many respects and sometimes it is hard to distinguish one position from another, especially when it comes to how mind begins to live in the body. Brentano seems to exaggerate Zeller's position in order to make his own views more reasonable (e.g. when it comes to preexistence or traducianism). 


\section{A Replay of History}

Below I will enumerate the contemporary readings of Aristotle's psychology that have ancient or medieval prototypes. The three readings I have chosen for this paper are: 1) Victor Caston's solution explicitly inspired by Alexander of Aphrodisias (Caston, 1999 which I have already sketched above), 2) Patrick Macfarlane's and Ronald Polansky's account from the 2009 paper inspired by Arabic Aristotelianism (Averroes, I believe), though rather loosely. Let me use this lengthy quotation (pp. 117-119) to present it:

What Aristotle is suggesting by his choice of imagery is that the socalled 'agent intellect' is just our knowledge that allows us to think the things that we know. Knowledge plays the role of moving cause for thinking. Knowledge is a disposition or a state (hexis) - having universals in the soul and or the capacity to demonstrate - that can be viewed as potentiality and/or actuality. (...) In the individual human the potentiality for learning precedes the possession of knowledge. But in humankind generally knowledge has priority since for Aristotle there are always humans, and therefore there is always knowledge. The individual learns through being taught by other humans. In this way mind seems to come from outside (see GA II 3, 736). What Aristotle proclaims does 'not sometimes think and sometimes not' is the knowledge either in the individual or in the humankind generally. (...) Aristotle goes on to say that this knowledge considered apart from the individual is immortal and eternal (430a). Such separate knowledge is a very impersonal sort of immortality. Mind and knowledge without any bodily apparatus to support the sense perception can have no memory since memory depends upon phantasia and sense perception, and therefore this is not a personal immortality. Yet that aspect of mind capable of supporting thinking by having knowledge to serve as agent mind, since knowledge is somehow eternal as its objects are eternal and divine, is eternal and divine mind. This view of mind shows how it can be divine. As not attached to a bodily organ, as having for its cognitive objects things that are not enmattered, it is somehow itself everlasting and divine. The knowledge of the individual and of humankind is thus eternal and divine: knowledge is an every-ready unmoved mover. But unlike God always thinking, also an unmoved mover, human knowledge need not always be moving a human to think. The human mind is a capacity for causing thinking: God is not merely a capacity. 
3) Lloyd P. Gerson's reading (Gerson, 2004). He believes that nous poietikos from De Anima is after all a human intellect (and moreover, that it is identical with nous pathetikos), whilst the divine intellect is described in Aristotle's Metaphysics. Let me explain here that the mystical readings, like Caston's for instance, rely on the conviction that De Anima and Metaphysics describe one and the same intellect and since it is only one, it must be divine.

\section{Suspension instead of an Ending}

This highly interesting thread must be stopped here as it would surpass the limits of this introductory text, but I hope to develop it elsewhere. In the close future, I wish to describe the models of life implied by both, mystical and rational interpretations. I will focus on finding out which line of interpretation is more appropriate for the genuine Aristotelianism (if such a thing exists). To achieve these goals, I will present them in light of Aristotle's definition of human beings (animal rationale), his understanding of God/Deity, and the visio beatituda of good life and potential immortality (Nicomachean Ethics). It may occur impossible to settle that the mystical interpretations are more adequate than the rational ones or the other way around and thus it may seem safer from this perspective to admit that mystical and rational motifs coexist in Aristotle. Let this last sentence be a punchline of the present paper and a motto for the one that is to come.

\section{Bibliography}

Aristotle (2003). Dzieła wszystkie. Warszawa: Wydawnictwo Naukowe PWN.

Aristotle (2017). On the Soul. Retrieved from: http://classics.mit.edu/Aristotle/ soul.3.iii.html (10.01.2017).

Aristotle (1963). On the Soul. Trans. J.A. Smith. In: W.D. Ross (ed.), The Works of Aristotle, vol. 3. Oxford: Oxford University Press.

Brentano, F. (1978). Aristotle and his World View. Trans. R. George, R.M. Chisholm. Berkeley: University of California Press.

Brentano, F. (1911a). Aristoteles Lehre vom Ursprung des menschlichen Geistes. Leipzig: Quelle \& Meyer.

Brentano, F. (1911b). Aristoteles und seine Weltanschauung. Leipzig. 
Brentano, F. (1977). The Psychology of Aristotle. Trans. R. George. Berkeley: University of California Press.

Caston,V. (1999). Aristotle's Two Intellects: A Modest Proposal. Phronesis, 44, 199-227.

Gerson, L.P. (2004). The Unity of Intellect in Aristotle's De Anima. Phronesis, 4 (XLIX), 348-373.

Kamińska, S. (2014a). Franz Brentano and His Competing World Views. Philosopher's Choice Between Science and Religion. Studia Religiologica, 4 (47), 285-294.

Kamińska, S. (2014b). The Alleged Activity of Active Intellect - A Wild Goose Chase or a Puzzle to be Solved. Zagadnienia Filozoficzne w Nauce, 54, 79-126.

Kamińska, S. (2012). What Can Grow from the Divine Seed? The Divinity of Human Beings According to Aristotle. Studia Religiologica, 3 (45), 173-182.

Kosman L.A. (1992). What Does the Maker Mind Make? In: M.C. Nussbaum, A. Oksenberg Rorty (eds.), Essays on Aristotle's De Anima (pp. 334-358). Oxford: Oxford University Press.

Macfarlane, P., Polansky, R. (2009). God, the Divine, and Noṽ in Relation to the "De Anima". In: G. Van Riel, P. Destrée (eds.), Ancient Perspectives on Aristotle's "De Anima" (pp. 107-123). Leuven: Leuven University Press,

Modrak, D.K.W. (1991). The Nous-Body Problem in Aristotle. The Review of Metaphysics, 4, 755-774.

Reale, G. (1990). A History of Ancient Philosophy: The Schools of the Imperial Age. Trans. J.R. Catan. New York: SUNY Press.

Sorabji, R. (2006). Self, Ancient and Modern Insights about Individuality, Life, and Death. Chicago: University of Chicago University Press.

Thomas Aquinas (1998). Selected Writings. London: Penguin Books Limited.

Thomas Aquinas (1999). Sententia libri De anima, Thomas Aquinas: a Commentary on Aristotle's De Anima. Trans. R. Pasnau. New Haven-London: Yale Library of Medieval Philosophy, Yale University Press.

Twardowski, K. (2009). Die Unsterblichkeitsfrage (The Problem of Immortality). Manuscript lecture notes, Spring Semester 1894/5, Vienna University, pp. 227. Online at http://www.elv-akt.net. Now edited by Michał Sepioło as Die Unsterblichkeitsfrage, Warszawa: Wydawnictwo WFiS UW, Twardowski Archives, Biblioteka IFiS PAN. 
Twardowski, K. (1895a). Filozofia współczesna o nieśmiertelności duszy. Przełom, 1 (14), 427-438.

Twardowski, K. (1895b). Metafizyka duszy. Przełom, 1 (15) 1895, 467-480.

Zeller, E. (1886). Outlines of the History of Greek Philosophy. Trans. S.F. Alleyne, E. Abbott. London: Longmans Green Co.

Wisnovsky, R. (2005). Avicenna and Avicennian Tradition. In: P. Adamson, R.C. Taylor (eds.), Cambridge Companion to Arabic Philosophy (pp. 92-136). Cambridge: Cambridge University Press.

\section{Summary}

In my paper, I will give an overview of the readings of nous poietikos, the active intellect from De Anima. Sadly, Aristotle describes it in a cryptic way, which resulted in many different theories. I will order them by introducing a division into "mystical" and "rational". The mystical ones are rooted in a view that nous poietikos does not belong to particular human beings, but is identical with Deity or a divine sphere. According to the rational readings it is our cognitive tool and through its activity we can learn about the Deity and emulate it. The mystics are: Eudemus, Avicenna, Averroes, from the newer philosophers E. Zeller and from the contemporary ones - V. Caston. The rationalists are: Theophrastus, Thomas Aquinas, the $\mathrm{XIX}^{\text {th }}$ century Aristotelian revival and from the contemporary thinkers - A. Kosman. 